\title{
Chemistry and Biology of Lipids
}

XII. The Group Lipoid of Pig Pancreas

By

\author{
Hajime Masamune, Masahiro Tokura and Ryosuke Satoh \\ （正宗 一) (登倉 正博) (俈藤良助)
}

(From the Medico-chemical Institute, Tohoku

University, Sendai)

(Received for publication, June 15, 1952)

14 fresh pig pancreases were separately stood with cold alcohol and the dehydrated materials treated with hot alcohol. The substances extracted with cold alcohol, the ones, precipitating and non-precipitating from the hot-alcoholic extracts when cooled, and the tissue residues were examined regarding the blood group activity. The third fractions all specifically inhibited the isoagglutination of $\mathbf{A}$ erythrocytes, whereas, of the first fractions, some could be recognized to effect the same action but some not due to hemolysis. The other fractions proved inactive. Next, the balance of the third fractions were combined and subjected to the procedure in preparing the group lipoids of human pancreases ${ }^{1)}$ with minor modifications. The divisions were tested on the sero-reactivity during the whole course, because between two kinds of animal, the corresponding substances of the same organs are not warranted to fall on the corresponding divisions in fractionation of the lipids in particular.

An electrophoretically homogeneous final product was much less active than the Group $\mathbf{A}$ lipoid of human pancreas and further diverged from the latter in composition to some extent.

\section{Experimental}

\section{Examination of the Blood Group Activity of Pig Pancreases}

14 fresh pig pancreases weighing from 42 to $115 \mathrm{~g}$. were separately masticated and preserved in 3 volumes of $91 \%$ denatured alcohol. 5 of them were stood for 6 weeks and the remaining for 1 year. The materials were then collected on a funnel and after drying in a Faust apparatus, boiled twice with 5 volumes of the denatured alcohol for 2 hours. The successive extracts of each material, filtered while hot, were combined, placed in an ice chest for 1 day, whereby a precipitate (II) occurred. The 


\section{TABLE I}

Weight of the Fractions of Pig Pancreases and Inhibition of Isoagglutination of Erythrocytes

-: group-inactive, + : Group $\mathbf{A}$ active, \pm : probable Group $\mathbf{A}$ activeness.

\begin{tabular}{|c|c|c|c|c|c|c|c|c|c|}
\hline \multicolumn{2}{|c|}{$\begin{array}{c}\text { Pig } \\
\text { pancreas }\end{array}$} & \multicolumn{2}{|c|}{$\begin{array}{l}\text { I* washed } \\
\text { with acetone }\end{array}$} & \multicolumn{4}{|c|}{ Hót-alcoholic extract } & \multicolumn{2}{|c|}{$\begin{array}{l}\text { Tissue residue } \\
\text { after hot-alcohol- } \\
\text { ic extraction }\end{array}$} \\
\hline \multirow{2}{*}{ No. } & \multirow{2}{*}{ wt. (g.) } & \multirow{2}{*}{ wt. (g.) } & \multirow{2}{*}{$\begin{array}{l}\text { group- } \\
\text { activity }\end{array}$} & \multicolumn{2}{|c|}{$\begin{array}{l}\text { II } \dagger \text { washed with } \\
\text { acetone }\end{array}$} & \multicolumn{2}{|c|}{$\begin{array}{l}\text { III+ washed with } \\
\text { acetone }\end{array}$} & \multirow{2}{*}{ wt. (g.) } & \multirow{2}{*}{$\begin{array}{l}\text { group- } \\
\text { activity }\end{array}$} \\
\hline & & & & wt. (g.) & group-activity & wt. (g.) & group-activity & & \\
\hline 1 & 46 & 1.4 & + & 0.02 & - & 0.5 & + & 4.0 & - \\
\hline 2 & 55 & 1.1 & \pm & 0.06 & - & 0.6 & + & 3.0 & - \\
\hline 3 & 115 & 2.6 & + & 0.09 & - & 1.0 & + & 8.7 & - \\
\hline 4 & 78 & 1.1 & \pm & 0.27 & - & 1.1 & + & 6.4 & - \\
\hline 5 & 98 & 3.1 & + & 0.09 & - & 1.0 & + & 6.9 & - \\
\hline 6 & 81 & & & 0.04 & - & 0.6 & + & 6.0 & - \\
\hline 7 & 64 & & & 0.18 & & 0.8 & + & 3.2 & \\
\hline 8 & 94 & & & 0.09 & & 0.9 & + & 6.2 & \\
\hline 9 & 42 & & & 0.02 & & 0.5 & + & 2.6 & \\
\hline 10 & 92 & & & 0.18 & & 0.8 & + & 7.7 & \\
\hline 11 & 38 & & & 0.01 & & 0.4 & + & 4.2 & \\
\hline 12 & 71 & & & 0.09 & & 0.6 & + & 2.9 & \\
\hline 13 & 96 & & & 0.18 & & 1.4 & + & 9.2 & \\
\hline 14 & 59 & & & 0.05 & & 0.3 & + & 2.1 & \\
\hline
\end{tabular}

* The fraction extracted with cold alcohol. $t$ The precipitate from the hotalcoholic extract on cooling. I The substance that had been recovered by distillation of the hot-alcoholic extract after cooling and removing of the precipitate.

\section{TABLE II}

Occurrence of Isohemoagglutination, when Fr.-I's, * washed with Acetone, had been added to the Normal Anti-sera

The $\mathbf{B}$ and $\mathbf{A}$ serum had agglutinin titres of 320 and 80 and were diluted 20 and 5 times respectively.

-: no agglutination, \pm : faint aggl., + : slight aggl., $\mathrm{H}$ : hemolysis.

\begin{tabular}{|c|c|c|c|c|c|c|}
\hline \multirow{2}{*}{$\begin{array}{l}\text { Pig pancreas } \\
\text { No. }\end{array}$} & \multirow{2}{*}{$\begin{array}{l}\text { Group of } \\
\text { red cells }\end{array}$} & \multicolumn{5}{|c|}{ Dilution of substances } \\
\hline & & $1: 10^{2}$ & $1: 2 \times 10^{2}$ & $1: 4 \times 10^{2}$ & $1: 8 \times 10^{2}$ & $1: 1: 6 \times 10^{3}$ \\
\hline 1 & $\begin{array}{l}\text { A } \\
\text { B }\end{array}$ & $\begin{array}{l}\mathrm{H} \\
\mathrm{H}\end{array}$ & $\begin{array}{l}\mathrm{H} \\
\mathrm{H}\end{array}$ & $\underset{\mathbf{H}}{\mathbf{H}},+$ & $\begin{array}{l}\mathrm{H} \uparrow,- \\
+\end{array}$ & $\begin{array}{l}+ \\
+\end{array}$ \\
\hline 2 & A & $\begin{array}{l}\mathrm{H} \\
\mathrm{H}\end{array}$ & $\begin{array}{l}\mathrm{H} \\
\mathrm{H}\end{array}$ & $\begin{array}{l}\mathrm{H} \\
\mathrm{H}\end{array}$ & $\begin{array}{l}\mathrm{H} \dagger, \pm \\
\mathrm{H} \dagger,+\end{array}$ & $\stackrel{+}{\mathrm{H}}+,+$ \\
\hline 3 & A & $\begin{array}{l}\mathrm{H} \\
\mathrm{H}\end{array}$ & $\begin{array}{l}\mathrm{H} \\
\mathbf{H}\end{array}$ & $\stackrel{\mathrm{H}}{\mathrm{H}}+,+$ & $\begin{array}{l}\mathrm{H} \dagger,- \\
+\end{array}$ & + \\
\hline 4 & $\begin{array}{l}\mathrm{A} \\
\mathrm{B}\end{array}$ & $\begin{array}{l}\mathrm{H} \\
\mathrm{H}\end{array}$ & $\begin{array}{l}\mathrm{H} \\
\mathrm{H}\end{array}$ & $\begin{array}{l}\mathrm{H} \\
\mathbf{H}\end{array}$ & $\begin{array}{l}\mathrm{H} \\
\mathrm{H} \dagger,+\end{array}$ & $\underset{+}{\mathrm{H}}+ \pm$ \\
\hline 5 & $\begin{array}{l}\mathrm{A} \\
\mathrm{B}\end{array}$ & $\begin{array}{l}\mathrm{H} \\
\mathrm{H}\end{array}$ & $\begin{array}{l}\mathbf{H} \\
\mathbf{H}\end{array}$ & $\begin{array}{l}\mathrm{H} \\
\mathrm{H}\end{array}$ & $\begin{array}{l}\mathrm{H}^{\dagger},-\overline{+} \\
\mathrm{H}+\end{array}$ & $\begin{array}{l}\mathrm{H} \dagger, \pm \\
+\end{array}$ \\
\hline
\end{tabular}

* Signifies the same as in Table I. † Hemolysis was partial. 
TABLE III

Occurrence of Isohemoagglutination, when Fr.-III's, * washed with Acetone, had been added to the Normal Anti-sera

The $\mathbf{B}$ and $\mathbf{A}$ serum had agglutinin titres of 320 and 80 and were diluted 20 and 5 times respectively.

-: no agglutination, \pm : faint aggl., + : slight aggl., H: marked aggl., H: complete aggl.

\begin{tabular}{|c|c|c|c|c|c|c|c|c|c|c|}
\hline \multirow{2}{*}{$\begin{array}{c}\text { Pig } \\
\text { pancreas } \\
\text { No. }\end{array}$} & \multirow{2}{*}{$\begin{array}{l}\text { Group } \\
\text { of red } \\
\text { cells }\end{array}$} & \multicolumn{9}{|c|}{ Dilution of substances } \\
\hline & & $1: 10^{2}$ & $1: 2 \times 10^{2}$ & $1: 4 \times 10^{2}$ & $1: 5 \times 10^{2}$ & $1: 8 \times 10^{2}$ & $1: 10^{3}$ & $1: 1.6 \times 10^{3}$ & $1: 5 \times 10^{3}$ & $1: 10^{4}$ \\
\hline 1 & $\begin{array}{l}\text { A } \\
\text { B }\end{array}$ & $\overline{+}$ & & & $\stackrel{ \pm}{H}$ & & $\begin{array}{l}+ \\
H\end{array}$ & & $\begin{array}{l}H \\
H\end{array}$ & $\begin{array}{l}\text { \# } \\
\text { H }\end{array}$ \\
\hline 2 & $\begin{array}{l}\text { A } \\
\text { B }\end{array}$ & $\overline{+}$ & & & $\bar{H}$ & & + & & $H$ & \# \\
\hline 3 & $\begin{array}{l}\text { A } \\
\text { B }\end{array}$ & $\bar{H}$ & & & $\bar{H}$ & & + & & H & 世 \\
\hline 4 & $\begin{array}{l}\mathrm{A} \\
\mathrm{B}\end{array}$ & $\bar{t}$ & $\bar{t}$ & $\bar{t}$ & & $\stackrel{ \pm}{+}$ & & + & & \\
\hline 5 & $\begin{array}{l}\mathrm{A} \\
\mathrm{B}\end{array}$ & $\overline{+}$ & $\overline{+}$ & $\overline{+}$ & & $\stackrel{+}{H}$ & & $\stackrel{+}{H}$ & & \\
\hline 6 & $\begin{array}{l}\text { A } \\
\text { B }\end{array}$ & $\vec{H}$ & & & $\bar{H}$ & & + & & H & $\begin{array}{l}\text { H } \\
\text { H }\end{array}$ \\
\hline 7 & $\begin{array}{l}\mathrm{A} \\
\mathrm{B}\end{array}$ & $\overline{+}$ & $\overline{+}$ & $\bar{t}$ & & $\overline{+}$ & & + & & \\
\hline 8 & $\begin{array}{l}\mathrm{A} \\
\mathrm{B}\end{array}$ & $\overrightarrow{+}$ & $\overline{+}$ & $\bar{H}$ & & $\begin{array}{r}+ \\
H\end{array}$ & & + & & \\
\hline 9 & $\begin{array}{l}\mathbf{A} \\
\mathbf{B}\end{array}$ & $\overline{+}$ & $\overline{+}$ & + & & $\stackrel{+}{+}$ & & $\begin{array}{l}H \\
H\end{array}$ & & \\
\hline 10 & $\begin{array}{l}\text { A } \\
\text { B }\end{array}$ & $\overline{+}$ & $\overline{+}$ & $\overline{+}$ & & $\begin{array}{l}+ \\
+\end{array}$ & & + & & \\
\hline 11 & $\begin{array}{l}\mathrm{A} \\
\mathrm{B}\end{array}$ & $\overline{+}$ & $\overline{+}$ & $\overline{+}$ & & $\begin{array}{l}+ \\
+\end{array}$ & & + & & \\
\hline 12 & $\begin{array}{l}\text { A } \\
B\end{array}$ & $\overline{+}$ & $\overline{+}$ & $\overline{+}$ & & $\overline{+}$ & & $\stackrel{+}{H}$ & & \\
\hline 13 & $\begin{array}{l}\text { A } \\
\text { B }\end{array}$ & $\overline{+}$ & + & + & & $\begin{array}{l}+ \\
H\end{array}$ & & $\begin{array}{l}H \\
H\end{array}$ & & \\
\hline 14 & $\begin{array}{l}\mathrm{A} \\
\mathrm{B}\end{array}$ & $\overrightarrow{+}$ & $\overline{+}$ & $\overline{+}$ & & $\overrightarrow{+}$ & & + & & \\
\hline
\end{tabular}

* Signifies the same as $\ddagger$ in Table I.

centrifuged supernatant was distilled to dryness (III). The alcohol portions used for the preservation were treated likewise, and the still residues thereby (I's) and the substances recovered from the hot alcoholic extracts were all washed with acetone and dried. III, washed with acetone, of all the pancreases were found to be specifically antiisoagglutinative to $\mathbf{A}$ erythrocytes. I's, washed with acetone, caused noticeable hemolysis so that definite judgement of the agglutination was allowed only in some of those tested, which indicated that the Group A lipoid had entered partially into the cold alcohol. The other fractions including the acetone-soluble and the tissue residues were inactive. A great part of the details of the experiment is embodied in Tables I, II and III. 


\section{Isolation of the Group Lipoid}

1st stage. The balance of Fr-III's, washed with acetone, of the pig pancreases above were combined ( $10.5 \mathrm{~g}$. altogether) and exhausted with three $150 \mathrm{cc}$. portions of ether (cold) and the solutions were distilled in

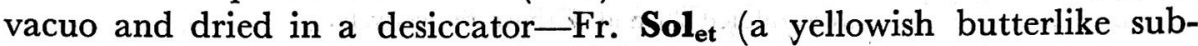
stance, $0.15 \mathrm{~g}$.). It showed no inhibition of the isoagglutination of $\mathbf{A}$ and B erythrocytes at a dilution of 1:200 (Complete hemolysis occurred at 1:100 dilution of the substance). The insoluble part-Fr. Ins et (a yellowish, non-sticky powder, 9.9 g.) was Group $\mathbf{A}$ active (inhibitory to isoagglutination of $\mathbf{A}$ erythrocytes at 1:500), but not reactive with $\beta$ agglutinin at 1:100. This was further divided, employing three $150 \mathrm{cc}$. portions of chloroform. The chloroform-soluble (Fr. Sol chl $_{\text {) }}$, recovered from the solutions similar to above, amounted to $0.5 \mathrm{~g}$. (a brownish, hard clump). When it was added, as dissolved in physiological saline, to the

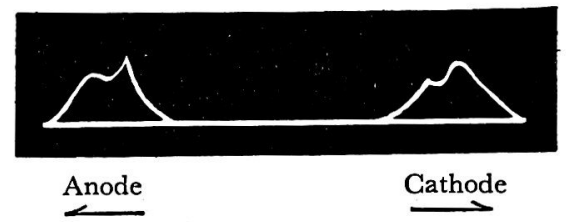

Fig. 1. An electrophoretic pattern of a $0.86 \%$ solution of Fr. Insch1 in phosphate buffer, $\mathrm{pH} 7.8, \mathrm{I}=0.29 ; 5^{\circ} \mathrm{G}$; current $10 \mathrm{ma}$. Exposure 60 minutes after starting current. Ascending limb to the right (Boundaries were shifted before photographing).

\section{TAB L E IV}

Occurrence of Isohemoagglutination, when Fractions at the

First Stage of Preparation had been added to the Normal Anti-sera

The $\mathbf{B}$ and $\mathbf{A}$ serum had agglutinin titres of 320 and 80 and were diluted 20 and 5 times respectively.

-: no agglutination, +: slight aggl., H: marked aggl., H: complete aggl., $\mathrm{H}$ : hemolysis.

\begin{tabular}{|c|c|c|c|c|c|c|c|c|c|c|c|}
\hline \multirow[b]{2}{*}{ Fraction } & \multirow{2}{*}{$\begin{array}{l}\text { Group of } \\
\text { red cells }\end{array}$} & \multicolumn{10}{|c|}{ Dilution of substances } \\
\hline & & $\begin{array}{l}1: \\
10^{2}\end{array}$ & $\begin{array}{l}1: \\
2 \times 10^{2} \\
\end{array}$ & $\begin{array}{l}1: \\
4 \times 10^{5}\end{array}$ & $\begin{array}{l}1: \\
5 \times 10^{2}\end{array}$ & $2 \begin{array}{l}1: \\
8 \times 10^{2}\end{array}$ & $\begin{array}{l}1: \\
10^{3}\end{array}$ & $\begin{array}{l}1: \\
1.6 \times 10^{3}\end{array}$ & $\begin{array}{l}1: \\
5 \times 10^{3}\end{array}$ & $\begin{array}{l}1: \\
10^{4}\end{array}$ & $\begin{array}{l}1 \\
5 \times 10^{4} \\
\end{array}$ \\
\hline Solet* & $\begin{array}{l}\text { A } \\
\text { B }\end{array}$ & $\begin{array}{l}\mathrm{H} \\
\mathrm{H}\end{array}$ & H & $\begin{array}{l}\text { W } \\
\text { H }\end{array}$ & & 册 & & $\begin{array}{l}\text { W } \\
\text { H }\end{array}$ & & & \\
\hline Inset* & $\begin{array}{l}\mathrm{A} \\
\mathrm{B}\end{array}$ & $\begin{array}{l}\mathrm{H} \\
+\end{array}$ & & & $\overline{+}$ & & + & & $\stackrel{+}{+1}$ & + & $\stackrel{+}{+}$ \\
\hline Solchl* & $\begin{array}{l}\text { A } \\
\text { B }\end{array}$ & $\begin{array}{l}\mathrm{H} \\
+\end{array}$ & $\begin{array}{l} \pm \\
+\end{array}$ & + & & + & & $\begin{array}{l}+ \\
H\end{array}$ & & & \\
\hline Inschl* & $\begin{array}{l}\text { A } \\
\text { B }\end{array}$ & $\begin{array}{l}\mathbf{H} \\
+\end{array}$ & & & $\bar{H}$ & & + & & + & + & + \\
\hline
\end{tabular}


normal antisera, $\mathbf{A}$ erythrocytes agglutinated only faintly at a dilution of $1: 200$ of it in the saline (hemolysis at 1:100) but $\mathbf{B}$ erythrocytes agglutinated markedly at its 1:100 dilution. The residue (Fr. Ins chi $_{\text {) }}$ - a yellowish, hygroscopic, fine powder - had the same Group A potency as the etherinsoluble, and gave positive Molisch and biuret reaction, and electrophoresis of a $0.86 \%$ solution (somewhat turbid) in a buffer of $\mathrm{pH} 7.8$ demonstrated two components (Fig. 1). This was mostly soluble in cold and hot methanol, cold neutral- and faintly-alkalinized-water, and hot acidulated water. Completely soluble in hot neutral- and faintly-alkalinizedwater. Insoluble in ether, petrol ether and chloroform.

(Serological potencies of the fractions above are illustrated in detail in Table IV.)

$2 n d$ stage. It was kneaded with a little water and water added up to $300 \mathrm{cc}$., followed by vigorous agitation. The centrifugate was further exhausted with two 300 cc. portions of water. The clear yellowish supernatant were united (100 cc. altogether) and added to with $90 \mathrm{cc}$. of $5 \%$ lead acetate, and the centrifugate here washed with changes of a dilute solution of the salt with centrifugation. The supernatant were bubbled with $\mathrm{H}_{2} \mathrm{~S}$. The black precipitate was separated and washed with hot water and the mother fluid and washings were distilled together to dryness and washed with acetone. $7.5 \mathrm{~g}$. of a yellowish hygroscopic, fine powder (Non-ppt pb ) were given which was group-inactive. The lead precipitate in $900 \mathrm{cc}$. of water was also treated with $\mathrm{H}_{2} \mathrm{~S}$ and the suspension was acidified to $\mathrm{pH} 1.0$ with $\mathrm{HCl}$. Centrifuged. The transparent yellowish supernatant was neutralized with $\mathrm{NaOH}$, distilled and washed with acetone. And $0.6 \mathrm{~g}$. of a brownish, very

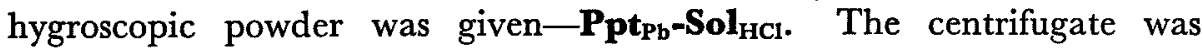
washed with three $50 \mathrm{cc}$. portions of a very dilute $\mathrm{HCl}(\mathrm{pH} \mathrm{1.0)}$ and then extracted repeatedly with methanol. In the second and following times, the extractant was added to with $\mathrm{HCl}$ to $\mathrm{pH} 6.0$ to obtain a clear centrifuged supernatant. The solutions were concentrated by vacuum distillation, neutralizing halfway and rejecting some precipitate thereby, to dryness. The remainder was washed with acetone. $670 \mathrm{mg}$. of a non-sticky powder with light yellow-brown shade were given-Ppt $\mathbf{P b}_{\mathbf{P b}}$

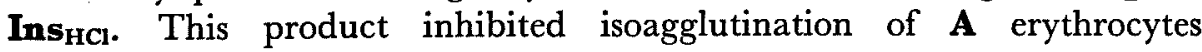
(complete inhibition at a dilution of $1: 1000$ ), but not that of $\mathbf{B}$ erythrocytes. Molisch positive, biuret negative. The electrophoresis revealed it was still heterogeneous. Here a $0.86 \%$ solution in an alkaline buffer was applied and two boundaries were demonstrated (Fig. 2). It was soluble partially in cold methanol, ethanol, benzene, tetralin and water, but mostly in hot methanol, ethanol and water and completely in hot tetralin and alkaline water. Insoluble was it in ether, petrol ether and chloroform. 
TABLE V

Occurrence of Isohemoagglutination, when Fractions at the

Second Stage of Preparation had been added to the Normal Anti-sera

The $\mathbf{B}$ and $\mathbf{A}$ serum had agglutinin titres of 320 and 80 and were diluted 20 and 5 times respectively.

-: no agglutination, +: slight aggl., + : marked aggl., H: complete aggl., $\mathrm{H}$ : hemolysis.

\begin{tabular}{|c|c|c|c|c|c|c|c|c|c|c|c|c|}
\hline \multirow[b]{2}{*}{ Fraction } & \multirow{2}{*}{$\begin{array}{c}\text { Group } \\
\text { of red } \\
\text { cells }\end{array}$} & \multicolumn{11}{|c|}{ Dilution of substances } \\
\hline & & $\begin{array}{l}1: \\
10^{2} \\
\end{array}$ & $\begin{array}{l}1: \\
2 \times 10^{2} \\
\end{array}$ & $\begin{array}{l}1: \\
4 \times 10^{2}\end{array}$ & $2 \begin{array}{l}1: \\
5 \times 10^{2}\end{array}$ & $\begin{array}{l}1: \\
8 \times 10^{2}\end{array}$ & $\begin{array}{l}1: \\
10^{3} \\
\end{array}$ & $\begin{array}{l}1: \\
1.6 \times 10^{3} \\
\end{array}$ & $\begin{array}{l}1: \\
5 \times 10^{3} \\
\end{array}$ & \begin{tabular}{|l|}
$1:$ \\
$10^{4}$ \\
\end{tabular} & $\begin{array}{l}1: \\
2 \times 10^{0}\end{array}$ & $4 \begin{array}{ll}11 \\
4 \times 10^{4}\end{array}$ \\
\hline Non-pptpb* & $\begin{array}{l}\mathrm{A} \\
\mathrm{B}\end{array}$ & 册 & \# & \# & & \# & & \# & & & & \\
\hline PptPb-SolHCl* & $\begin{array}{l}\mathrm{A} \\
\mathrm{B}\end{array}$ & H & 册 & 册 & & 世 & & 世 & & & & \\
\hline PptPb-InshCl* & $\begin{array}{l}\mathrm{A} \\
\mathrm{B}\end{array}$ & $\overline{\mathrm{H}}$ & & & $\bar{t}$ & & $\vec{H}$ & & + & + & $\stackrel{+}{\mathrm{H}}$ & H \\
\hline
\end{tabular}

* See the text.

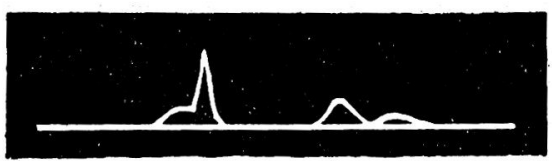

\section{$\stackrel{\text { Anorde }}{\longrightarrow} \stackrel{\text { Cathode }}{\longrightarrow}$}

Fig. 2. An electrophoretic pattern of a $0.86 \%$ solution of PptpbInsHCl in phosphate buffer, $\mathrm{pH} 7.8, \mathrm{I}=0.29$ (The substance was dissolved in the buffer by warming at $30^{\circ} \mathrm{C}$ for 2 minutes.); $5^{\circ} \mathrm{C} ; 10 \mathrm{ma}$. Exposure 40 minutes after starting current. Ascending limb to the left.

3rd stage. $0.3 \mathrm{~g}$. of it was subjected to the procedure of counter current distribution, employing 10 funnels. Solvent pair, an equilibrated mixture of methanol, benzene, toluene and water $(4: 4: 1: 1)$. The substance was at first dissolved in $150 \mathrm{cc}$. of the lower phase and distributed between that solvent and an equal volume of the upper phase. After the last transfer the content of all the funnels were distilled separately and the residuals washed with acetone and dried.

\begin{tabular}{|c|c|c|c|c|c|c|c|c|c|c|}
\hline \multirow[b]{3}{*}{$\begin{array}{l}\text { Weight of } \\
\text { the products } \\
\text { (mg.) }\end{array}$} & \multicolumn{10}{|c|}{ Funnel No. } \\
\hline & 0 & 1 & 2 & 3 & 4 & 5 & 6 & 7 & 8 & 9 \\
\hline & 6 & 6 & 11 & 15 & 15 & 17 & 15 & 15 & 20 & 130 \\
\hline
\end{tabular}

Their anti-isohemoagglutinative potencies are illustrated in Table VI, which shows the fraction from Funnel 9 only was definitely group (A)-active. 
TABLE VI

Occurrence of Isohemoagglutination, when Fractions in the

Third Stage of Preparation had been added to the

Normal Anti-sera

The $\mathbf{B}$ and $\mathbf{A}$ serum had agglutinin titres of 320 and 80 and were diluted 20 and 5 times respectively.

- : no agglutination, \pm : faint aggl., + : slight aggl., H: marked aggl., H: complete aggl., H: hemolysis.

\begin{tabular}{|c|c|c|c|c|c|c|c|c|c|c|c|c|c|c|}
\hline \multirow[b]{2}{*}{ Fraction* } & \multirow[b]{2}{*}{$\begin{array}{c}\text { Group } \\
\text { of red } \\
\text { cells }\end{array}$} & \multicolumn{13}{|c|}{ Dilution of substances } \\
\hline & & $\begin{array}{l}\stackrel{\leftrightarrow}{0} \\
\ddot{-}\end{array}$ & $\begin{array}{l}\text { go } \\
\underset{O}{x} \\
\stackrel{-}{-}\end{array}$ & 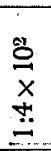 & 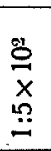 & 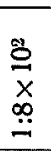 & $\stackrel{\text { 号 }}{\stackrel{-}{ت}}$ & $\begin{array}{l}\tilde{y} \\
\stackrel{0}{x} \\
0 \\
0 \\
\dddot{\leftrightarrow}\end{array}$ & 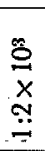 & 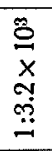 & 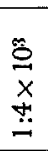 & 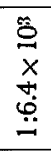 & $\begin{array}{l}\stackrel{\tilde{O}}{0} \\
\dot{x} \\
\stackrel{\infty}{-} \\
\end{array}$ & 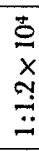 \\
\hline 0 & $\begin{array}{l}\mathrm{A} \\
\mathrm{B}\end{array}$ & & + & + & & + & & + & & + & & & & \\
\hline I & $\begin{array}{l}\text { A } \\
\text { B }\end{array}$ & & + & + & & + & & + & & + & & & & \\
\hline 2 & $\begin{array}{l}\text { A } \\
\text { B }\end{array}$ & & + & + & & + & & + & & + & & & & \\
\hline 3 & $\underset{\mathrm{B}}{\mathrm{A}}$ & & + & + & & + & & + & & + & & & & \\
\hline 4 & $\stackrel{\text { A }}{\text { B }}$ & & + & + & & $\begin{array}{l}+ \\
H\end{array}$ & & $\stackrel{+}{+}$ & & + & & & & \\
\hline 5 & $\begin{array}{l}\text { A } \\
\text { B }\end{array}$ & & + & + & & $\begin{array}{l}+ \\
+\end{array}$ & & $\begin{array}{l}+ \\
H\end{array}$ & & $\begin{array}{l}+ \\
H\end{array}$ & & & & \\
\hline 6 & $\underset{B}{A}$ & & + & + & & + & & + & & + & & & & \\
\hline 7 & $\underset{B}{A}$ & & $\stackrel{\mathrm{H}}{\mathrm{H}}$ & $\begin{array}{l}\mathrm{H} \\
+\end{array}$ & & $\begin{array}{l}\mathrm{H} \\
+\end{array}$ & & + & & + & & & & \\
\hline 8 & $\stackrel{\text { A }}{B}$ & & & & $\begin{array}{l}\mathrm{H} \\
\mathrm{H}\end{array}$ & & $\begin{array}{l}\mathbf{H} \\
+\end{array}$ & & $\begin{array}{l}+ \\
+\end{array}$ & & $\begin{array}{l}+ \\
+\end{array}$ & & + & \\
\hline 9 & $\begin{array}{l}\text { A } \\
\text { B }\end{array}$ & & & & $\begin{array}{l}\mathrm{H} \\
+\end{array}$ & & $\begin{array}{l}\mathrm{H} \\
+\end{array}$ & & + & & \pm & & + & \\
\hline 9-Inst & $\underset{\mathbf{B}}{\mathbf{A}}$ & $\begin{array}{l}\mathrm{H} \\
\mathrm{H}\end{array}$ & $\begin{array}{l}\mathrm{H} \\
\mathrm{H}\end{array}$ & $\begin{array}{l}\mathrm{H} \\
\mathrm{H}\end{array}$ & & $\begin{array}{l}\mathrm{H} \\
\mathrm{H}\end{array}$ & & $\begin{array}{l}\mathrm{H} \\
\mathbf{H}\end{array}$ & & $\begin{array}{l}\mathrm{H} \\
\mathbf{H}\end{array}$ & & & & \\
\hline 9-Solt & $\begin{array}{l}\mathrm{A} \\
\mathrm{B}\end{array}$ & $\begin{array}{l}\mathbf{H} \\
\mathbf{H}\end{array}$ & $\begin{array}{l}\mathrm{H} \\
\mathrm{H}\end{array}$ & $\begin{array}{l}\mathrm{H} \\
+\end{array}$ & & $\begin{array}{l}\mathrm{H} \\
+\end{array}$ & & $\overline{+}$ & & $\begin{array}{l} \pm \\
H\end{array}$ & & + & & + \\
\hline
\end{tabular}

* Figures express funnel numbers. + See the text.

In a similar run with the balance of the product in the foregoing stage (320 mg.), $140 \mathrm{mg}$. of a substance, washed with acetone, were recovered from Funnel 9.

The substances yielded in the both runs $(265 \mathrm{mg}$. altogether) were shaken with $30 \mathrm{cc}$. of water on an apparatus for 6 hours and centrifuged. On the centrifugate was repeated the. operation many times (300 cc. of water used in total). The insoluble part (a powder tinged yellowish) -9-Ins-amounted to $15 \mathrm{mg}$., and in the examination of the group 
activity it caused complete hemolysis even at the dilution of $1: 3,200$ (Table VI). The solutions were distilled in vacuo and washed with acetone$240 \mathrm{mg}$. of a yellowish non-sticky powder (9-Sol) were given. This product was specifically Group $\mathbf{A}$ active. It also exhibited hemolytic action, though not strong, probably due to a trace of the water-insoluble part contaminating (Table VI). Electrophoretically it was homogeneous as is shown in Fig. 3.
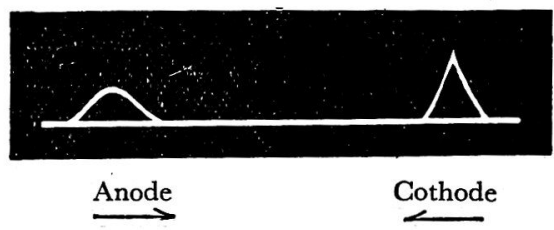

Fig. 3. An electrophoretic pattern of a $0.67 \%$ solution of 9-Sol in phosphate buffer, $\mathrm{pH} 7.8, \mathrm{I}=0.29 ; 11^{\circ} \mathrm{C} ; \mathrm{I} 5 \mathrm{ma}$. Exposure 60 minutes after starting current. Mobility $2.03 \mathrm{~cm}^{2} \cdot \mathrm{volt}^{-1} \cdot \mathrm{sec}^{-1} \cdot 10^{5}$. Ascending limb to the left.

Since, however, it contained an abundant amount of ash $(64.4 \%$, Pregl's method without use of $\left.\mathrm{H}_{2} \mathrm{SO}_{4}\right), 130 \mathrm{mg}$. of it were electrodialyzed as dissolved in $7 \mathrm{cc}$. of water (Pauli apparatus) until no shift of $\mathrm{pH}$ occurred in the outer fluids ( 2 days requisite). The substance precipitated thereby in part, but because of difficulty in separating the precipitate, the solution containing it was distilled as such in vacuo and dehydrated with acetone. A yellowish powder weighing $30 \mathrm{mg}$. was provided. Biuret, Goldschmiedt (for hexuronic acid), Neuberg \& Saneyoshi (for hexuronic acid) and Rosenthaler (for methylpentose) negative; Molisch and Elson \& Morgan positive: Composition, group-activity and solubilities are shown in Tables VII, VIII and IX.

\section{TABLE VII}

Composition of the Final Preparation of Pig Pancreas Group Lipoid

\begin{tabular}{c|c|c}
\multicolumn{1}{c|}{ Analysis } & In per cent & In equiv. per equiv. wt. \\
\cline { 1 - 2 } $\mathrm{N}$ & 4.2 & 2.9 \\
$\mathrm{P}$ & 3.2 & 1.0 \\
Ferricyanide reduction of the & 9.2 & \\
hydrolystate* as glucose & 3.5 &
\end{tabular}

* The substance was hydrolyzed by 4 hours' heating with $1 \mathrm{~N} \mathrm{H}_{2} \mathrm{SO}_{4}$, as sealed in an ampoule. The hydrolysate contained none precipitable by phosphotungstic acid so that it was immediately neutralized for measurement of the reduction. † Pregl method without $\mathrm{H}_{2} \mathrm{SO}_{4}$. 


\section{TABLE VIII}

Occurrence of Isohemoagglutination, when the Final Preparation had been added to the Normal Anti-sera

The $\mathbf{B}$ and $\mathbf{A}$ serum had agglutinin titres of 320 and 80 , and were diluted 20 and 5 times respectively.

-: no agglutination, +: slight aggl., H: marked aggl., H: complete aggl., $\mathrm{H}$ : hemolysis.

\begin{tabular}{|c|c|c|c|c|c|c|}
\hline \multirow{2}{*}{$\begin{array}{l}\text { Group of } \\
\text { red cells }\end{array}$} & \multicolumn{6}{|c|}{ Dilution of the substance } \\
\hline & $\begin{array}{l}1: \\
5 \times 10^{2}\end{array}$ & $\begin{array}{l}1: \\
10^{3}\end{array}$ & $\begin{array}{l}1: \\
2 \times 10^{3}\end{array}$ & $\begin{array}{l}1: \\
4 \times 10^{3}\end{array}$ & $\begin{array}{l}1: \\
8 \times 10^{3}\end{array}$ & $\begin{array}{l}1: \\
1.6 \times 10^{4}\end{array}$ \\
\hline $\begin{array}{l}\text { A } \\
\text { B }\end{array}$ & $\begin{array}{l}\mathrm{H} \\
+\end{array}$ & $\begin{array}{l}\mathbf{H} \\
+\end{array}$ & - & $\begin{array}{l}+ \\
+\end{array}$ & $\begin{array}{l}+ \\
+\end{array}$ & + \\
\hline
\end{tabular}

TABLE IX

Solubilities of the Final Preparation

-: insoluble, \pm : faintly sol., + : partly sol., $H$ : mostly sol., H: completely sol., cold $=20^{\circ} \mathrm{C}$, hot $=50-60^{\circ} \mathrm{C}$.

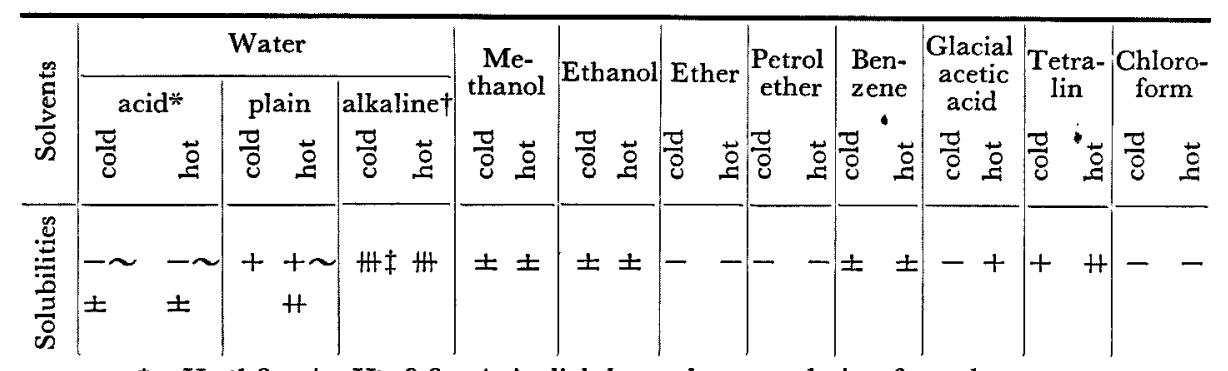

* $\mathrm{pH}<1.2, \dagger \mathrm{pH}>9.6, \ddagger \mathrm{A}$ slightly opalescent solution formed.

Compared with the corresponding substance of human pancreas, the following remarks are given as to the present group lipoid:-1) it is much less group-active; 2) the potency is not diminished by the third stage-operation; 3) the equivalent ratio of $\mathrm{N}$ and $\mathrm{P}$ of it (2.9:1.0) does not agree with that of the one in human pancreas $(1.9: 1.0) ; 4)$ it contains less carbohydrate and more $\mathbf{N}$ and $\mathbf{P}$ than the human substance.

\section{SUMMARY}

14 pig pancreases contained all a Group $\mathbf{A}$ lipoid. The tissue residues after extraction with hot alcohol was group-inactive.

The group lipoid was prepared in an electrophoretically homogeneous state. It analyzed: $\mathrm{N} 4.2 \%, \mathrm{P} 3.2 \%$, ferricyanide reduction of the hydrolysate as glucose $9.2 \%$, ash $3.5 \%$; and inhibited specifically the isoagglutination of $\mathbf{A}$ erythrocytes at a dilution of $1: 2 \times 10^{3}$. It dissolved 